\title{
Corn Drying with Zeolite in The Fluidized Bed Dryer under Medium Temperature
}

\author{
Mohamad Djaeni ${ }^{1}$, Nurul Aishah ${ }^{2}$, Harum Nissaulfasha ${ }^{2}$, Luqman Buchori ${ }^{1}$
}

\begin{abstract}
Drying is an important step to find high quality of corn. Based on Standard of National Industry, populer as SNI, number 01-3920-1995, the corn was well stored at moisture content 14\% or below (wet basis). However, conventional corn drying dealed with in-efficient energy process and corn quality degradation. This research evaluated the performance of corn drying assisted by zeolite as moisture adsorbent. In this process, the zeolite and corn were placed in the dryer fluidized by warm air as drying medium under $40-50^{\circ} \mathrm{C}$. The air evaporated water product from corn, and at same time the zeolite adsorbed moisture in air. So, the relative humidity of air in dryer can be kept low in which enhanced the driving force for drying. Beside that, the moisture adsoprtion by zeolite was exothermic process that can supply the energy for drying or keep the dryer temperature. Thus, the drying rate can be faster. This work foccussed to observe the effect of drying temperature, air velocity, and corn to zeolite ratio on drying time as well as corn quality. As indicators, the drying rate was estimated and the proxymates content such as protein, fat, and carbohydrate content were analyzed. The results showed that compared with conventional fluidised bed dryer, corn drying with zeolite, can speed up drying time as well as improving the constant of drying rate. In addition, the corn proximate nutrition content can be well retained. At operating temperature $40^{\circ} \mathrm{C}$, air velocity $9 \mathrm{~m} . \mathrm{s}^{-1}$, and zeolite to corn ratio 1:2, the drying time can be 60 minutes shorter compared to that without zeolite.
\end{abstract}

Keywords - Corn, zeolite, fluidized bed dryer, drying rate

Abstract - Pengeringan merupakan tahap yang penting untuk menjaga kualitas jagung selama masa penyimpanan. Sesuai SNI 01-3920-1995 kualitas jagung akan terjaga dengan baik apabila disimpan dalam kadar air dibawah 14\% (basis basah). Tetapi, teknologi pengeringan jagung konvensional terkendala dengan ketidakefisienan energi dan turunnya mutu selama proses. Penelitian ini mempelajari pengaruh zeolite untuk meningkatkan performansi pengering. Dalam proses ini zeolite dan jagung dimasukkan dalam unggun dan difludisasikan dengan udara pada suhu $40-50^{\circ} \mathrm{C}$. Udara menguapkan air dari jagung, dan pada saat yang sama, zeolite $n$ menyerap air dari udara. Sehingga kelembaban udara dalam kolompengering dapat dijaga rendah, yang akan meningkatkan driving force pengeringan. Disamping itu, penyerapan air oleh zeolite merupakan proses eksotermis yang akan menyediakan panas sensibel untuk proses pengeringan. Sehingga proses dapat lebih cepat. Pada tahap ini mengkaji pengaruh suhu, kecepatan udara, dan zeolite terhadap waktu pengeringan dan mutu jagung. Sebagai indikator, kecepatan pengeringan dihitung, dan kandungan nutrisi jagung seperti protein, karbohidrat dan lemak, dianalisa. Hasil menunjukkan bahwa dibandingkan dengan pengeringan konvensional, pengeringan jagung dengan zeolite mampu mempercepat proses pengeringan serta meningkatkan konstanta kecepatan pengeringan. Terlebih lagi, kandungan nutrisi dalam jagung juga dapat dijaga tetap tinggi. Pada suhu $40^{\circ} \mathrm{C}$, kecepatan udara $9 \mathrm{~m} . \mathrm{s}^{-1}$, dan rasio zeolite terhadap jagung $1: 2$, waktu pengeringan 60 menit lebih cepat dari pengeringan tanpa zeolite.

Kata Kunci-Jagung, zeolite, unggun terfluidisasi, kecepatan pengeringan

\section{INTRODUCTION}

$\mathrm{C}$ orn (Zea mays L.) is one of main food resources in the world. Corn kernels, on the average, contain up to $16 \%$ moisture, $72 \%$ starch and $9-10 \%$ protein [1]. Normally, moisture content of freshly harvested corn varies in a range of $33-40 \%$. At this moisture level under hot and humid climates, Aspergillus flavus easily infects in corn kernels and produces aflatoxin substance [2]. Post harvest treatment such as drying is an important step to produce high quality of corn since it determines the life time of storage by inhibiting microbacteria or fungi activities called SNI number 01-3920-1995). With this condition, the microbial activity is decreased thus corn can be either stored or marketed in a long time period.

Corn should be stored as dried product with a water content below 14\% (National Standard Industry, Indonesia,

\footnotetext{
${ }^{1}$ Mohammad Djaeni and Luqman Buchori are the lecturer at Department of Chemical Engineering, Faculty of Engineering, Diponegoro University ${ }^{2}$ Harum Nissaulfasha and Nurul Aishah are Master Student at Department of Chemical Engineering, Faculty of Engineering, Diponegoro University Jl Prof H. Soedharto, SH, Tembalang, Semarang, Indonesia.50275 Email: m.djaeni@undip.ac.id; mzaini98@yahoo.com
}

Some drying methods have been used in drying process, such as direct sun drying, convective drying, microwave and infra-red drying, freeze and vacuum drying. Current drying technology is often in efficient in energy consumption and has a high environmental impact because of combustion of fossil fuel or wood as energy source [3].

From all of the existed methods, Soponronnarit, et al (1997) stated that the fluidized bed dryer is widely used in many industries because of its advantages such as high rates of heat and mass transfer, short drying time, small dryer with high capacity, and easy controlled [4]. However, the energy efficiency is still below than $50 \%$. For example, corn drying with conventional fluidized bed dryer operated in $130-$ $170^{\circ} \mathrm{C}$ needed $5-7 \mathrm{MJ} / \mathrm{kg}$ water evaporated. It means that 5 $-7 \mathrm{~kg}$ steam was required to evaporate $1 \mathrm{~kg}$ water from corn or energy efficiency ranged $28-50 \%$. While former method formulated by Meiering et al (1977) showed by recycing of sensible heat at exhaust air exiting dryer, the energy efficiency achieved $60 \% \quad(10 \%$ higher than that of conventional fluidized bed dryer) [5]. The research was continued in 1982 in which indicated that the lower temperature resulted lower energy efficiency [6]. 
Jittanit, et al (2010) also attempted to increase the performance of fluidized corn and rice by implementing two stages dryer [7]. This process can reduce operational temperature as well as improve the quality of corn during storage. However, the operating temperature is still higher than $60^{\circ} \mathrm{C}$ and considered to degrade the ingredients. Lynch and Morey (1989) in their research suggested that ambient air corn drying gives better in corn quality compared to high temperature drying [8].

Considering the corn quality as well as energy efficiency, mixed-adsorption drying using water absorbent such as zeolite is studied. Based on Revilla et al (2006), the effect of zeolite in removing water from a grain product (corn and seed) is more superior than silica, alumina, sand and pillared clay [9].

Drying process modification was operated by applying mixed adsorption dryer $[10,11,12]$. For example, the zeolite and corn were mixed at different percentage in a column. Then, the mixture was fluidized by air as drying medium at various velocity and temperature. The air will evaporate water from the product, and at the same time, zeolite will adsorb vapour from air. As consequence, the air humidity can be kept low. Moreover, operational temperature can be maintained at the certain condition due to the latent heat of adsorption. So, the driving force of drying can be kept high $[10,12]$. The result showed that at operational drying temperature below $70^{\circ} \mathrm{C}$, the drying time can be 20 - 40 minutes faster than that of conventional dryer. However, the important drying parameter such as water diffusivity and constant of drying rate were not estimated, yet $[10,12]$.

This paper discussed the effect of drying condition on key paramater of corn drying with zeolite. In this study, the air temperature, air velocity and zeolite to corn ratio in fluidized bed column were varied. As responses, the water diffusivity, drying rate constant, and drying time were estimated. In addition, the corn quality were observed.

\section{MATERIAL AND MethodS}

The research was conducted in two steps. Firstly, the experiment was performed to find the real data about the effect of air temperature, air velocity, and zeolite to corn ratio on corn drying. As responses water and proximate content (carbohydrate, protein, and fats) were observed. Secondly, the mathematical modelling was developed and validated using experimental data to find water diffusivity, constant of drying rate, as well as drying time.

\section{A. Experimental Set Up}

The corn drying was carried out in fluidized bed dryer presented in Figure 1. The dryer basically consisted of a blower to supply the air flow, a fluidized column, an electric heater and an electronic temperature controller. The air velocity required was measured with an Extech Instruments Thermo-Anemometer 407113.The sweet corn was harvested from local farmer in Semarang with average initial moisture content of $30 \%$. Zeolite used in this research was Zeolite 3 A provided by Zeochem, Switzerland [10, 12].
Fresh corn kernels with total weight of $10 \mathrm{~kg}$ and initial moisture content about $30 \% \pm 2 \%$ (wet basis) was used. For experiment, the 150 grams of corn was taken and fluidized with air at operational temperature $40^{\circ} \mathrm{C}$.

In the first experiment, the air velocity of $9 \mathrm{~m} . \mathrm{s}^{-1}$ was applied based on Ergun's equation (two times minimum velocity). The water content in the corn was measured every 10 minutes during the process using KW06-404 Grain Moisture Meter assembled by Krisbow Indonesia. To ensure the accuracy, the apparatus was callibrated and checked with water content analysis by gravimetry. The process was terminated when the moisture content reached to $14 \%$. The moisture content versus time was then plotted in the graph and used for estimating water difusivity, constant of drying rate, and drying time. Furthermore, the corn proximate quality was also analysed in term of protein (by Kjedahl), carbohydrate (by Fehling Test), and fat (by AOAC gravimetric method). These procedures were repeated for zeolite to corn ratio $(1: 1$ and $1: 2)$, operational temperature $50^{\circ} \mathrm{C}$, and air velocity 11 and $13 \mathrm{~m} \cdot \mathrm{s}^{-1}$.

\section{B. Water diffusivity, drying rate constant, and drying time estimation}

In this step, the water diffusivity, drying rate constant, and drying time were estimated referring to the common literatures. Jangam and Mujumdar (2010) have given diffusions mechanism of drying process. The drying rate can be estimated when the value of diffusivity was known [13]. The diffusivity was a function of both moisture content of the material and drying temperature. Some mathematical equations had developed to calculate the value of moisture diffusivity in falling rate period. The moisture diffusivity is estimated using the equation derived by Boudhrioua et al (2003) [14].

$\ln \left(\frac{q_{a, p}-q_{w, p}}{q_{a, p}-q_{w, 0}}\right)=\ln \left(\frac{8}{\pi^{2}}\right)-\frac{\pi^{2} D t}{d^{2}}$

Where $\mathrm{t}$ is sampling time (s), $d$ is the average diameter of corn $(\mathrm{m}), \mathrm{q}_{\mathrm{w}, \mathrm{p}}$ is the moisture in corn at sampling time ( $\mathrm{kg}$ water/ $\mathrm{kg}$ dry corn), and $\mathrm{q}_{\mathrm{e}, \mathrm{p}}$ is the moisture loaded in corn at equilibrium ( $\mathrm{kg}$ water $/ \mathrm{kg}$ dry corn). Moisture content of material is absorbed when the value of $\mathrm{q}_{\mathrm{e}, \mathrm{p}}$ less then $\mathrm{q}_{\mathrm{w}, \mathrm{p}}$. Based on Oswin's equation the equilibrium moisture content for corn is expressed as:

$q_{e, p}=\left(\frac{13,77-0,077 T_{a}}{100}\right)\left(\frac{a_{w}}{1-a_{w}}\right)^{0,33}$

Where $a_{w}$ is the water activity which is assumed to be equal to the Relative Humidity $(R H)$ and Ta is drying air temperature.

The value of moisture content and humidity were collected from experiment; as a result the value of diffusivity can be calculated.

The relation between diffusivity and the drying mass transfer coefficient can be presented based on sherwood number $(S h)$ as follow:

$S h=2,0+0,55 R e^{0,53} S c^{1 / 3}$

Schmidt and Reynold number can be calculated by:

$S c=\frac{v_{a}}{D}$

$R e=\frac{\stackrel{D}{\rho}_{a} L v_{a}}{\mu_{a}}$

Where $v_{a}$ is drying air velocity $(\mathrm{m} / \mathrm{s}), \mathrm{L}$ is characteristic travelled length $(\mathrm{m}), \mu$ is dynamic viscosity of air and $\rho$ is 
density of air. By applying these equations, the value of drying time can be estimated by Lewis equation. ([15], [16], [17], [18]).

$\mathrm{MR}=\exp (-\mathrm{kt})$

$k=\frac{\operatorname{sh} D}{2}$

Where MR is moisture ratio, $\mathrm{k}$ is mass transfer coefficient and $\mathrm{t}$ is drying time.

\section{RESULTS AND DISCUSSION}

\section{A. The Effect Of Different Composition Between Zeolite And Corn}

The effect of zeolite in the corn drying was presented in Fig. 2. The corn drying with zeolite required shorter time compared to the that of without zeolite (conventional fluidized bed dryer). For example, at zeolite to corn ratio 1:2 (by weight), the drying time to reach 0.12 gr water/gr dry corn or $14 \%$ moisture (wet basis) was about 70 minutes. In contrast, the corn drying without zeolite needed 150 minutes for same level moisture content. Compare with literatures, the drying with zeolite performed in this method can shorten drying time $0.75-1.0$ hours $[4,5,6,7]$. The time was shorter at higher zeolite in the mixture (zeolite to corn ratio 1:1). It can be also noted that drying with zeolite can speed up twice times shorter.

Using Figure 2, the drying rate was estimated based on amount of water evaporated per $\mathrm{cm}^{2}$ per second. Results were presented in Figure 3. At the beginning of drying process, the curve showed the constant rate period. The overall drying rate of that period is determined solely by external heat and mass transfer conditions to the material being dried, such as the temperature, gas velocity, total pressure and partial pressure of the vapor. It means that various drying temperature and drying velocity were predicted to give a significant effect in the drying time. Further, after constant period, drying curve is continued by falling rate period, where the drying rate is determined by internal heat and mass transfer [9].

Referring to the Figure 3, the corn drying with zeolite resulted faster drying rate. This because of the zeolite removed water in the air by adsorption process. With higher zeolite, more water can be up taken from the air in the dryer. Thus, the humidity of air can be kept low in which enhanced the driving force for drying. The faster drying rate gave the larger surface area below the curve in which implied much more water can be evaporated. Hence, the drying time, for same water evaporation load was shorter.

Relative humidity in dryer influences the equilibrium moisture content $\left(\mathrm{q}_{\mathrm{e}, \mathrm{p}}\right)$ of the system as expressed in Equation 2. Using the value of relative humidity depicted in Table 1, the moisture diffusivity was estimated with Equation 1. The diffusivity was used for estimating constant of drying as expressed in Equation 3. The result was listed in Table 2. Here, the value of moisture diffusivity as well as constant of drying rate were also linear with the presence of zeolite in the mixture. Thus, the higher zeolite, the greater moisture diffusivity and constant of drying rate.

\section{B. The Effect Of Drying Air Temperature}

In the drying process, air temperature influenced the moisture diffusion. The higher operational temperature reduced the relative humidity of air as well as moisture equilibrium loaded in the corn (see Equation 2). With lower equilibrium moisture, the water can diffuses form inside to the surface of corn easily. Moreover, with higher temperature, the corn will get more sensible heat used for water evaporation. Therefore, the evaporation rate in surface area per hour increased [16,17]. This condition was represented by Figure 4 . The drying time at air velocity 9 $\mathrm{m} . \mathrm{s}^{-1}$ and zeolite to corn ratio $1: 1$, was calculated and shown in Table 3. Based this result, it can be noted that higher operational temperature, higher drying rate. Hence, the shorter drying time was obtained. The simple correlation was expressed by Arrhenius equation where the drying rate was exponentially expressed as a function of temperature.

$$
k=A e^{-\frac{E}{R T}}
$$

Here, $\mathrm{A}$ is constant $\left(\mathrm{s}^{-1}\right), \mathrm{E}$ is activation energy per kMole water evaporated $(\mathrm{kJ} / \mathrm{kMole}), \mathrm{R}$ is constant of energy component $(8.314 \mathrm{~kJ} / \mathrm{kMole} / \mathrm{K}), \quad \mathrm{T}$ is operational temperature $(\mathrm{K})$.

\section{B. The Effect Of Drying Air Velocity}

The effect of air velocity on the drying process was presented in Figure 5. The moisture content of the corn was more rapidly reduced at higher air velocity. The phenomena can be simply explained as follows:

At the high air velocity, the corn can be easily fluidized. As a result, the mass and heat transfer in the bed can be easily carried. So, the water evaporation from the corn raised. Figure 5 showed that the increase of air velocity resulted shorter drying time. For example, for air velocity 9 $\mathrm{m} . \mathrm{s}^{-1}$, drying time was about 70 minutes, while at 11 and 13 $\mathrm{m} . \mathrm{s}^{-1}$, the drying time were 60 and 50 minutes, respectively.

The air velocity has a positive effect on the constant of drying rate. The higher air velocity increased the Sherwood number (see Equation 4 to 6). As a result, the value of drying rate constant estimated with equation 3 became higher as depicted in Table 4.

\section{Effect Of Process Variable In Product Quality}

The protein in the corn and other heat sensitive materials will degrade at temperature upper $60^{\circ} \mathrm{C}$. The corn drying at $40^{\circ} \mathrm{C}$ and $50^{\circ} \mathrm{C}$ were recommended for grain material [19, 20]. Table 5 proved that the corn drying with zeolite conducted under $60^{\circ} \mathrm{C}$ retained proxymate nutrition content (carbohydrater, protein, and fat). Based on that data, the increase of air temperature from 40 to $50^{\circ} \mathrm{C}$ did not affect the proximate content significantly. The same story also occured in the increase of air velocity where the proximate quality can be well retained.

\section{CONCLUSIONS}

The experiment and model approach were conducted to prove that corn drying with zeolite gave the positive effect on drying rate, drying time and corn quality. The works confirmed that the adsorption dryer with zeolite was potential for corn drying. Compared with conventional fluidised bed dryer, corn drying with zeolite, can speed up drying time as well as improving the constant of drying rate. In addition, the corn proximate nutrition can be well retained. From the experiment, it can be noted that higher 
air velocity and zeolite ratio accelarate drying process as well as product quality enhancement. While, the increase of temperature shortened drying time, but it reduced product quality. In this research, the operational drying temperature ranging $40-50^{\circ} \mathrm{C}$ was still recommended. At operating temperature $40^{\circ} \mathrm{C}$, air velocity $9 \mathrm{~m} . \mathrm{s}-1$, and zeolite to corn ratio $1: 2$, the drying time can be 60 minutes shorter compared to that without zeolite.

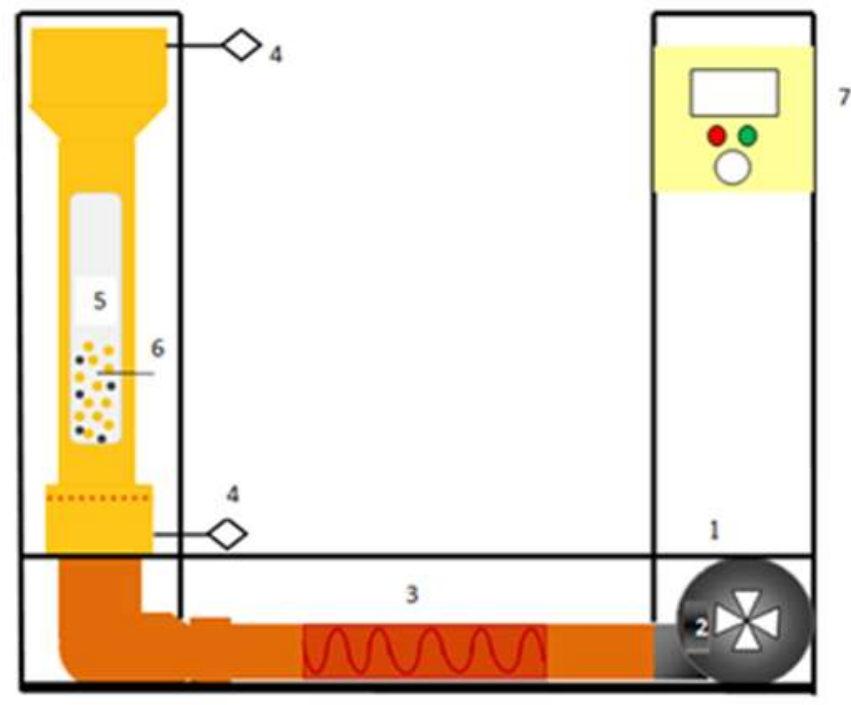

Figure 1. The schematic overview of mixed-adsorption fluidized bed dryer: 1: blower; 2: valve blower; 3 : Heater; 4 : Temperature and relative humidity sensor; 5: fluidized column; 6: Mixed-bed; 7: Temperature controller Figure 2 . The drying time versus moisture content at drying temperature $40^{\circ} \mathrm{C}$ and air velocity $9 \mathrm{~m} . \mathrm{s}^{-1}$

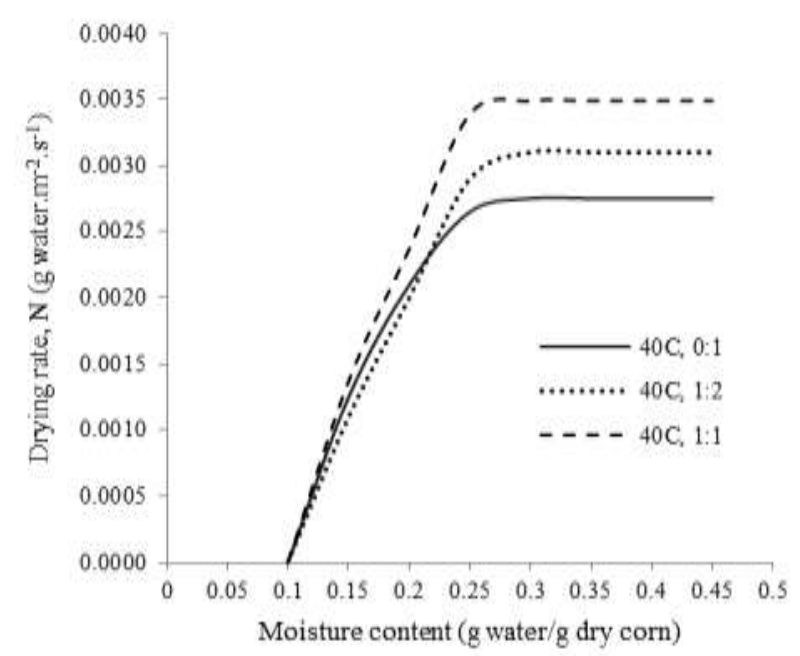

Figure 3. Drying rate versus moisture in corn at operational temperature $40^{\circ} \mathrm{C}$ and air velocity $9 \mathrm{~m} . \mathrm{s}^{-1}$

\section{ACKNOWLEDGMENT}

The authors would like to thank to Director Research and Community Service General Directory of High Education Ministry of Education and Culture for National Strategic Grant year $2012 \quad$ Contract Number 008/SP2H/PL/Dit.Litabmas/III/2012 date March, $7^{\text {th }} 2012$.
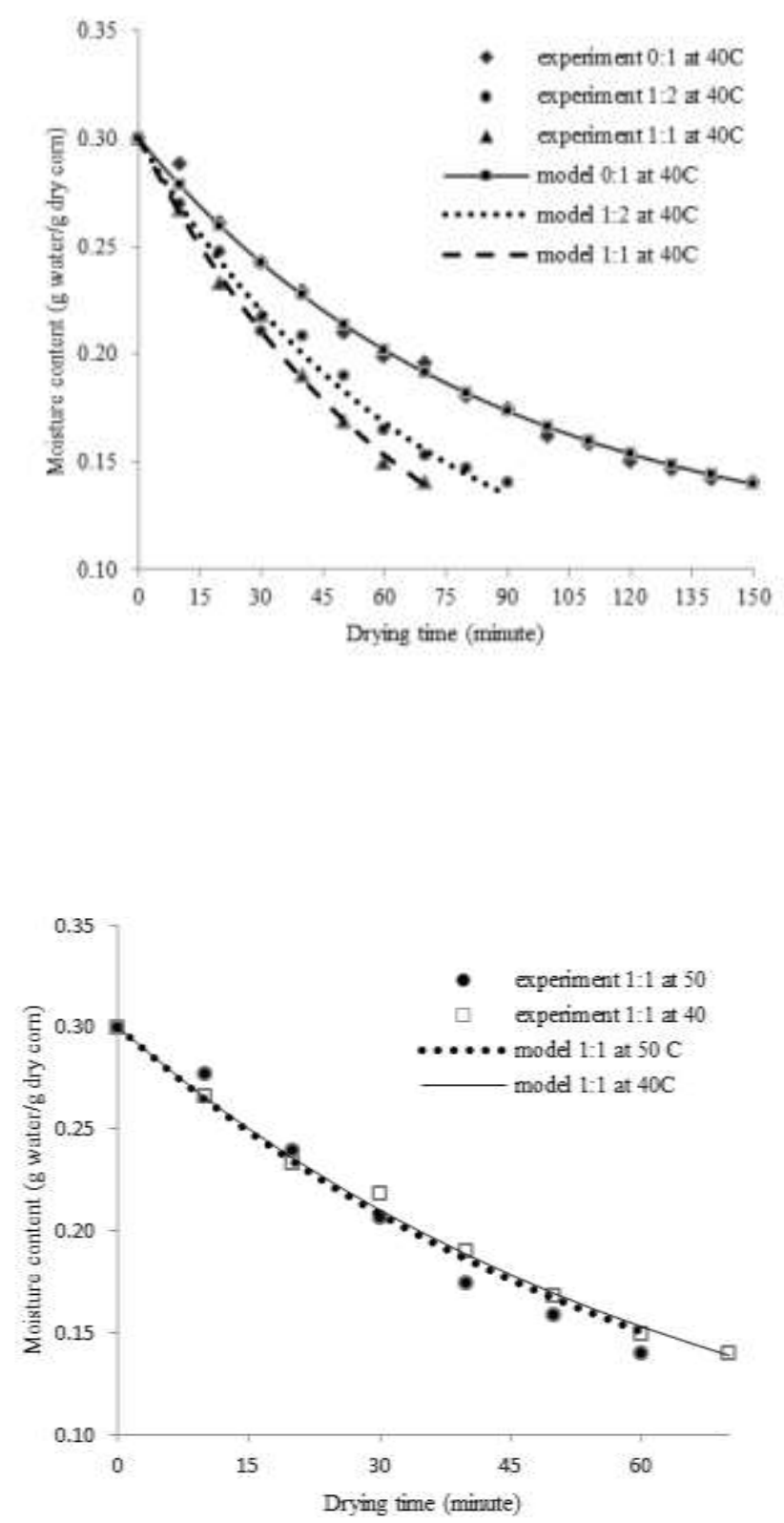

Figure 4. The drying time versus moisture content at zeolite and zeolite to corn ratio $1: 1$ and air velocity $9 \mathrm{~m} . \mathrm{s}^{-1}$ 


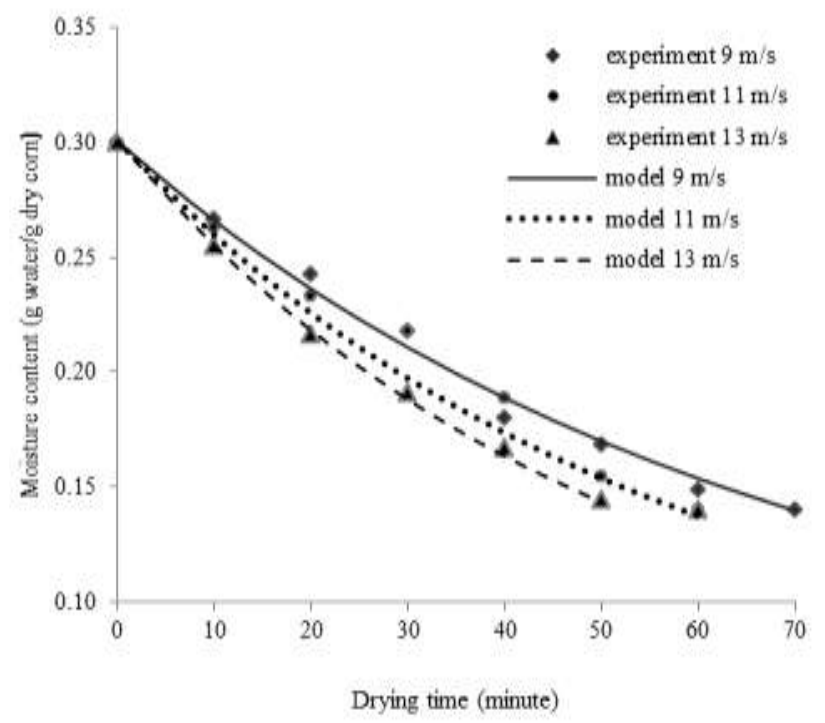

Figure 5. The drying time versus moisture content at zeolite to corn ratio $1: 1$ and air temperature $50^{\circ} \mathrm{C}$

TABLE 1.

THE VALUE OF WATER LOADED IN CORN AT EQUILIBRIUM

\begin{tabular}{ccccc}
\hline & \multicolumn{2}{c}{$\mathrm{RH}$} & \multicolumn{2}{c}{$\mathrm{Xe}$} \\
\cline { 2 - 5 } $\begin{array}{c}\text { Perbandingan } \\
\text { zeolite : corn }\end{array}$ & $40^{\circ} \mathrm{C}$ & $50^{\circ} \mathrm{C}$ & $40^{\circ} \mathrm{C}$ & $50^{\circ} \mathrm{C}$ \\
\hline $0: 1$ & 50 & 45 & 0,11 & 0,08 \\
$1: 2$ & 40,7 & 34,7 & 0,07 & 0,05 \\
$1: 1$ & 32,26 & 27,6 & 0,05 & 0,04 \\
\hline
\end{tabular}

TABLE 3.

THE VALUE OF WATER DIFFUSIVITY, SHERWOOD NUMBER, MASS TRANSFER COEFFICIENT, AND DRYING TIME AT ZEOLITE TO CORN RATIO 1:1 AND AIR VELOCITY $9{\mathrm{M} . \mathrm{S}^{-1}}^{-1}$

\begin{tabular}{|c|c|c|c|c|c|}
\hline Temperature & RH & $\begin{array}{c}\text { Diffusivity } \\
\left(\mathrm{x} 10^{-10}\right) \\
\mathrm{m}^{2} \cdot \mathrm{s}^{-1}\end{array}$ & $\begin{array}{l}\text { Sherwood } \\
\text { Number }\end{array}$ & $\begin{array}{c}\mathrm{k}\left(\mathrm{x} 10^{-4}\right) \\
\mathrm{s}^{-1}\end{array}$ & $\begin{array}{c}\text { Drying } \\
\text { Time } \\
\text { minute }\end{array}$ \\
\hline 40 & 32,26 & 6,03 & 5985,45 & 2,48 & 69,13 \\
\hline 50 & 27,6 & 6,50 & 5401,30 & 2,58 & 60,91 \\
\hline
\end{tabular}

TABLE 5.

THE VALUE OF PROTEIN, CARBOHYDRATE AND FAT AFTER DRYING

\begin{tabular}{|c|c|c|c|}
\hline Input change & Protein $(\%)$ & Carbohydrate (\%) & Fat $(\%)$ \\
\hline \multicolumn{4}{|c|}{ Temperature $\left({ }^{0} \mathrm{C}\right)$ at air velocity $9 \mathrm{~m} \cdot \mathrm{s}^{-1}$} \\
\hline 40 & 0,73 & 7,5 & 0,20 \\
\hline 50 & 0,70 & 7,4 & 0,21 \\
\hline \multicolumn{4}{|c|}{ Air velocity $\left(\mathrm{m} . \mathrm{s}^{-1}\right)$ at operational temperature $40^{\circ} \mathrm{C}$} \\
\hline 9 & 0,73 & 7,5 & 0,20 \\
\hline 11 & 0,75 & 7,6 & 0,20 \\
\hline 13 & 0,75 & 7,7 & 0,21 \\
\hline
\end{tabular}

\section{REFERENCES}

[1] G.W. Dickerson, :Nutritional Analysys of New Mexico Blue Corn and Dent Corn Kernels", College of Agriculture and Home Economics Guide H-233 pp. 1-2, 2003.

[2] A. Wongurai, 0. Tsuruta, and K. Arai, "Water Activity of Thai Maize and Growth of Aspergillus Flavus". Research Report of Maize Quality Improvement Research Centre Project. pp. 7 - 9, 1992.

[3] T. Kudra, and A.S. Mujumdar. "Advanced Drying Technology". Marcel Dekker Inc., New York, USA, 2002.
TABLE 2.

THE VALUE OF WATER DIFFUSIVITY, SHERWOOD NUMBER, MASS TRANSFER COEFFICIENT, AND DRYING TIME AT AIR

TEMPERATURE $40^{\circ} \mathrm{C}$, AND ZEOLITE TO CORN RATIO $1: 1$

\begin{tabular}{cccccc}
\hline $\begin{array}{c}\text { Ratio } \\
\text { Zeolite : corn }\end{array}$ & $\mathrm{RH}$ & $\begin{array}{c}\text { Diffusivity } \\
\left(\mathrm{x} 10^{-10}\right) \\
\mathrm{m}^{2} \cdot \mathrm{s}^{-1}\end{array}$ & $\begin{array}{c}\text { Sherwood } \\
\text { Number }\end{array}$ & $\mathrm{k}\left(\mathrm{x} 10^{-4}\right)$ & $\begin{array}{c}\text { Drying } \\
\text { time } \\
\text { minute }\end{array}$ \\
\hline $0: 1$ & 50 & 4,28 & 5985,45 & 1,97 & 148,98 \\
$1: 2$ & 40,7 & 5,83 & 5401,30 & 2,42 & 84,20 \\
$1: 1$ & 32,26 & 6,03 & 5340,12 & 2,48 & 69,13 \\
\hline
\end{tabular}

TABLE 4

THE VALUE OF WATER DIFFUSIVITY, SHERWOOD NUMBER, MASS TRANSFER COEFFICIENT, AND DRYING TIME AT TEMPERATURE $50^{\circ} \mathrm{C}$, ZEOLITE TO CORN RATIO $1: 1$

\begin{tabular}{ccccc}
\hline $\begin{array}{c}\text { Air } \\
\text { Velocity } \\
\mathrm{m}^{-1} \mathrm{~s}^{-1}\end{array}$ & $\begin{array}{c}\text { Diffusivity } \\
\left(\mathrm{x} 10^{-10}\right) \\
\mathrm{m}^{2} \cdot \mathrm{s}^{-1}\end{array}$ & $\begin{array}{c}\text { Sherwood } \\
\text { Number }\end{array}$ & $\mathrm{k}\left(\mathrm{x} 10^{-4}\right)$ & $\begin{array}{c}\text { Drying } \\
\text { time } \\
\text { minute }\end{array}$ \\
\hline 9 & 6,16 & 5303,25 & 2,51 & 69,74 \\
11 & 6,90 & 5680,67 & 3,01 & 58,16 \\
13 & 7,17 & 6124,93 & 3,38 & 51,85 \\
\hline
\end{tabular}


[6] G.S. Mittal, and L.Ottern, "Simulation of Low Temperature Corn Drying". Canadian Agriculture Engineering, Vol. 24 No. 2, pp. 111 $-118,1982$.

[7] W.Jittanit, G. Srzednicki, and R. Driscoll, "Corn, Rice, And Wheat Seed Drying by Two-Stage Concept". Drying Technology,Vol. 28 No. 6, 807-815.

[8] B.E. Lynch and R.V. Morey, "Control Strategies for Ambient Air Corn Drying". Transaction of the American Society of Agricultural Engineers, 32(5), 75-79, 1989.

[9] G.O. Revilla, T.G. Velázquez; S.L. Cortés.; S.A. Cárdenas, Immersion drying of wheat using Al-PILC, zeolite, clay, and sand as particulate media. Drying Technology, Vol. 24 No. 8, pp. 1033-1038, 2006.

[10] M. Djaeni, Hargono, and L. Buchori, The Effect of Zeolite On Drying Rate Of Corn In Mixed-Adsorption Dryer. 7th Asia-Pacific Drying Conference (ADC 2011) Tianjin, China, September $26^{\text {th }}-28^{\text {th }}, 2011$.

[11] M. Djaeni, L. Kurniasari, A. Purbasari, and S.B. Sasongko, "Activation of Natural Zeolite as Water Adsorbent for MixedAdsorption Drying". Proceeding of International Conference on Material Engineering, Gadjah Mada University, Yogyakarta Indonesia, November $26^{\text {th }}-27^{\text {th }}, 2010$.

[12] H. Nissaulfasha, M. Djaeni, and L. Buchori, "Mixed Adsorption Dryer In Fluidized Bed For Corn Drying : The Effect of Temperature And Superficial Air Velocity To Moisture Content of Corn". Proceeding International Student Conference: The Power of Local Knowledge in Increasing Food Business Competitivenes. 1, pp. 114118, 2012.

[13] S.V. Jangam, and A.S. Mujumdar, "Basic Concepts and Definitions". Drying of Foods, Vegetables and Fruits. Ed. Jangam, S.V., Law, C.L. and Mujumdar, A.S. ISBN - 978-981-08-6759-1. Singapore. 1: pp.1$30,2010$.

[14] N. Boudhrioua, C. Bonazzi, and J.D. Daudin, "Estimation Of Moisture Diffusivity In Gelatin-Starch Gels Using Time-Dependent Concentration-Distance Curves At Constant Temperature". Food Chemistry, Vol. 82 No. 1, pp.139-149, 2003.

[15] T.K. Nguyen, "Convective Mass Transfer". Mass Transfer. California State Polytechnic University, Pomona. USA, 2011.

[16] P.S. Takhar, "Hybrid Mixture Theory Based Moisture Transport And Stress Development In Corn Kernels During Drying: Coupled Fluid Transport And Stress Equations". Journal of Food Engineering. 105, pp. 663-670, 2011.

[17] D. Marinos-Kouris, and Z.B. Maroulis, Transport Properties in The Drying of Solids. Handbook of Industrial Drying. Taylor \& Francis Group, LLC, 2006.

[18] M.C. Falabella, C. Suarez, and P.E. Viollaz, "Drying Kinetics of Corn in Contact with a Solid Adsorbent". Journal of Food Engineering. 13, pp. 273-283, 1991.

[19] C.W. Hall, Drying and storage of agricultural corps. West port, CT:AVI, 1980.

[20] P. Malumba, C. Vanderghem, C. Deroanne, and F. Bera, Influence of drying temperature on the solubility, the purity, of isolates and electrophoretic patterns of corn protein. Food Chemistry. 111, pp.564-572, 2008 . 